\title{
PROFESOR TOMASZ DYBOWSKI
}

„Dobrze kiedy uczniowie pamiętają o swoim Profesorze, tym bardziej, że ... jest godny, aby się na nim wzorować”. Te słowa Ojca Świętego - skierowane do mnie, kiedy wręczałem Mu podczas audiencji generalnej na Placu Świętego Piotra numer «Prawa Kanonicznego» poświęcony świętej pamięci Profesorowi Henrykowi Kupiszewskiemu - stały się zachętą, by w osiemdziesiątą rocznicę urodzin uczcić wybitnego cywilistę Profesora Tomasza Dybowskiego, który mimo szykan i upokorzeń potrafił skutecznie bronić swoich poglądów i przekonań, dając przykład otwartej i niezależnej postawy, dzięki czemu stał się niekwestionowanym autorytetem moralnym i naukowym.

Jakkolwiek pracę naukową Profesor Dybowski uprawia na Uniwersytecie Warszawskim, to czynnie włączył się, jak wcześniej Henryk Kupiszewski, a później Jan Błeszyński i Adam Brzozowski, w tworzenie niemal od podstaw Wydziału Prawa Kanonicznego Akademii Teologii Katolickiej, obecnie Uniwersytetu Kardynała Stefana Wyszyńskiego. Nic więc dziwnego, że wspólnie z wybitnymi kanonistami, takimi jak: Marian Myrcha, Marian Żurowski, Tadeusz Pawluk i Remigiusz Sobański, stworzyli we wspaniałej atmosferze podstawy i zręby solidnej szkoły. Pracę Profesora Dybowskiego na Wydziale Prawa Kanonicznego można uznać za wspaniały fragment jego kariery naukowo-dydaktycznej. Osoba zaś Profesora jest żywą legendą tego Wydziału. Wykłada tam prawo cywilne od 1972 r. (najpierw w ramach umowy zlecenia, od 1983 r. na pół etatu, od 1992 r. na pełnym etacie), od 1996 r. pełni też funkcję kierownika Katedry Prawa Cywilnego, a przede wszystkim bierze udział w sympozjach oraz przewodach doktorskich i habilitacyjnych, gdzie stawia proste i dociekliwe pytania, domagając się precyzyjnej odpowiedzi. Nieraz samo postawienie takiego pytania, a potem subtelna sugestia jak roz- 
wiązać problem, jest ciekawsze niż sama obrona. Zatrudniony tego samego dnia w ATK co Profesor, mam nieraz okazję spotykać się z Nim, dyskutować, a przede wszystkim uczyć się od Niego. Profesora poznałem bliżej, kiedy prowadziłem ćwiczenia $\mathrm{z}$ prawa zobowiązań. Wtedy też chodziłem na Jego wykłady. Potem na dobre zająłem się historią prawa i prawem rzymskim, ale nasze spotkania nadal były częste, czy to przy okazji układania planu zajęć, czy posiedzeń Rady Wydziału Prawa Kanonicznego. Profesor nigdy nie szczędzi czasu i wysiłku dla dobra Wydziału. Przygotowując na Wydziale Prawa UKSW czasopismo «Zeszyty Prawnicze», zaprosiłem Go do Rady Naukowej. Miał tylko jedno pytanie: „co w tej Radzie będę robił?”. „Nic - odpowiedziałem - tylko Pan Profesor będzie miał zaszczyt pierwszy czytać to, co napiszą młodzi cywiliści”. Profesor przyjął propozycję z komentarzem: „to się zgadzam, bo figurantem nie chcę być”. Tym razem proponuję Panu Profesorowi lekturę tego, co napisali wdzięczni Mu najbliżsi współpracownicy, przyjaciele, koledzy i uczniowie, by uczcić Jego osiemdziesiątą rocznicę urodzin.

Tomasz Dybowski urodził się 29 grudnia 1923 r. w Białymstoku. W przedwojennej polskiej szkole ukończył trzy klasy gimnazjum. W latach 1940-1941 naukę kontynuował w dziesięciolatce radzieckiej. Maturę zdał na tajnych kompletach podczas okupacji niemieckiej. Wtedy też pracował jako goniec i działał w Armii Krajowej. Po wyparciu okupanta niemieckiego, w sierpniu 1944 r., podjął pracę w Urzędzie Wojewódzkim w Białymstoku. Po pięciu miesiącach pracy został aresztowany i uwięziony przez UB. Po powrocie do Polski Stanisława Mikołajczyka, dzięki częściowym zwolnieniom z więzień, wyszedł na wolność i natychmiast udał się do Krakowa, by podjąć studia na Wydziale Prawa Uniwersytetu Jagiellońskiego. Po pierwszym roku przeniósł się na Wydział Prawa Uniwersytetu Warszawskiego, gdzie w 1949 r. ukończył studia i przeszedł wszystkie szczeble kariery naukowej. Początkowo zatrudniony był w Katedrze Teorii Prawa UW, jednak w 1952 r. opuszcza ją, na polecenie, ze względów „ideologicznych”. Na szczęście pozwolono Mu na pracę w Katedrze Prawa Cywilnego, w której w 1958 r. został mianowany adiunktem. Stopień naukowy doktora nauk prawnych uzyskał 
w 1960 r. pisząc pracę pt. Wtasność wód. Została ona w zasadniczej części opublikowana w książce Zagadnienia cywilistyczne prawa wodnego, Warszawa 1957. Za pracę doktorską otrzymał w 1961 r. II nagrodę w konkursie «Państwa i Prawa». Habilitował się w 1969 r. na podstawie rozprawy Ochrona wtasności ('rei vindicatio' - 'actio negatoria'), Warszawa 1969. Za tę rozprawę otrzymał nagrodę III stopnia Ministra Oświaty i Szkolnictwa Wyższego. W czerwcu 1970 r. został powołany na stanowisko docenta w Instytucie Prawa Cywilnego UW. W 1980 r. otrzymał tytuł naukowy profesora, a w 1993 r. stanowisko profesora zwyczajnego. Uchwałą Sejmu z dnia 29 kwietnia 1989 r. został wybrany na Sędziego Trybunału Konstytucyjnego, gdzie orzekał do przejścia w 1998 r. w stan spoczynku. Przejście w stan spoczynku nie zahamowało aktywności Profesora. Nadal prowadzi zajęcia ze studentami i pracuje naukowo oraz czynnie uczestniczy w pracach wielu instytucji.

W czasie pracy na Uniwersytecie pełnił wiele funkcji, a zwłaszcza kierownika Zakładu Prawa Cywilnego (1976-1994), dyrektora Instytutu Prawa Cywilnego (1985-1990). Był ponadto członkiem Rady Naukowej Instytutu Historii Prawa, wreszcie przewodniczącym Rady Fundacji Uniwersytetu Warszawskiego.

Przez wiele lat prowadził różnorakie zajęcia dydaktyczne, ćwiczenia, konwersatoria, wykłady kursowe i monograficzne, seminaria, wykłady na studiach podyplomowych i doktoranckich. W latach 1977-1978 oraz 1978-1979 został uznany w plebiscytach studentów WPiA UW za najlepszego wykładowcę. Pisane pod Jego kierunkiem prace magisterskie były wielokrotnie nagradzane na różnych konkursach ogólnopolskich.

Jest bardzo cenionym wychowawcą młodej kadry naukowej. Od wielu lat prowadzi seminarium doktoranckie $\mathrm{z}$ prawa cywilnego. Pod jego kierunkiem stopnie doktora nauk prawnych uzyskali: Joanna Błeszyńska-Wysocka, Aleksander Chłopecki, Elżbieta Holewińska-Łapińska, Maciej Kaliński, Marek Safjan, Elżbieta Skowrońska, Cezary Wiśniewski i Ewa Wojtaszek-Mik a spośród nich veniam legendi otrzymali Aleksander Chłopecki, Elżbieta Holewińska-Łapińska, Marek Safjan i Elżbieta Skowrońska. 
Wielokrotnie też występował jako recenzent w przewodach doktorskich $\mathrm{i}$ habilitacyjnych oraz $\mathrm{w}$ postępowaniach o nadanie tytułu profesora.

Brał czynny udział w wielu konferencjach krajowych i międzynarodowych, współorganizował międzynarodowe sympozjum prawników polskich i włoskich poświęcone tradycjom romanistycznym we współczesnym prawie, które odbyło się w listopadzie 1978 r. w Popowie. Prowadził też wykłady w uniwersytetach zagranicznych.

Aktywnie współpracował ze studentami w ramach ruchu studenckiego. W czasie kiedy był opiekunem naukowym Koła Naukowego Prawników, członkowie Koła zdobyli wiele nagród na ogólnopolskich seminariach i sympozjach.

Profesor był lub jest członkiem: Komitetu Nauk Prawnych PAN, Komisji Legislacyjnej przy Premierze Rady Ministrów, Prezydium Komisji Reformy Prawa Cywilnego przy Ministrze Sprawiedliwości, Komisji Prawa Cywilnego działającej przy Zarządzie Głównym ZPP, Sekcji Polskiej Towarzystwa Francuskiej Kultury Prawniczej im. Henri Capitant, Instytutu Wymiaru Sprawiedliwości, ekspertem kilku komisji Sejmu i Senatu. Czynnie uczestniczy w pracach wielu redakcji: Komitetu Redakcyjnego «Nowego Prawa», «Przeglądu Sądowego», Komitetu Redakcyjnego «Studiów Prawniczych» PAN, Komitetu Redakcyjnego «Centralnego Zautomatyzowanego Rejestru Aktów Normatywnych» przy Bibliotece Sejmowej, Komitetu Naukowego «Jus matrimoniale», Rady Programowej «Zeszytów Prawniczych» UKSW.

Profesor Dybowski jest wszechstronnym cywilistą, a jego publikacje koncentrowały się wokół trzech głównych obszarów tematycznych.

Pierwszy to problematyka prawa rzeczowego, a w szczególności prawa własności i zagadnień pokrewnych. Są to zagadnienia dotyczące własności wód, a także sporów w doktrynie na temat własności oraz ochrony prawnej własności. Z problematyką prawa rzeczowego wiążą się opracowania poświęcone zasadom współżycia społecznego, analizujące przeobrażenia w dziedzinie stosunków własnościowych, dotyczące sytuacji prawnej mienia ogólnonarodowe- 
go czy mienia samorządu terytorialnego, wreszcie dotyczące przedsiębiorstw w warunkach reformy gospodarczej.

Drugi obejmuje stosunki zobowiązaniowe, przede wszystkim problematykę świadczenia i obowiązku naprawienia szkody, a także odpowiedzialności odszkodowawczej z tytułu naruszenia posiadania oraz związku przyczynowego i przyczynienia się do powstania szkody.

Trzeci dotyczy zagadnień z zakresu prawa rodzinnego, takich jak przysposobienie, problematyka rozwodowa na tle orzecznictwa i doktryny oraz kierunki rozwoju prawa rodzinnego.

Z chwilą wyboru na Sędziego Trybunału Konstytucyjnego zakres zainteresowań Profesora poszerzył się o szeroko rozumiane zagadnienia konstytucyjne.

Publikacje Profesora spotykają się z wielkim uznaniem środowiska cywilistycznego. Wiele zagadnień trudnych i skomplikowanych udało się w nich rozwikłać. Najważniejsza dotycząca ochrony własności, mimo upływu czasu pozostaje wciąż fundamentalnym dziełem polskiej cywilistyki. Jego badania są prowadzone na bogatym materiale porównawczym, a rozważania, wyważone i precyzyjne, wywierają silny wpływ na dalsze badania oraz na orzecznictwo sądowe.

$\mathrm{Z}$ opinii legislacyjnych Profesora wiele wykorzystano przy nowelizacji prawa, m.in. dotyczących realizacji zasady równości podmiotów prawa cywilnego w stosunkach nowego modelu gospodarczego w okresie postkomunistycznym, kwestii zabezpieczenia wierzyciela $\mathrm{z}$ tytułu udzielonego kredytu na nieruchomościach i w drodze hipoteki, zabezpieczeń w drodze zastawu, klauzuli rebus sic stantibus.

Większość prac Profesora Dybowskiego jest rozproszona po trudno dostępnych czasopismach krajowych i zagranicznych. Za wskazówkę ich poszukiwań, zanim zostaną zebrane i wydane, służyć może zamieszczona poniżej bibliografia. 


\section{BIBLIOGRAFIA PUBLIKACJI PROFESORA TOMASZA DYBOWSKIEGO}

1955

W sprawie wykładni art. 152 § 1 k.z., «NP» 11.7-8 (1955), s. 98-103.

1956

Wtasność wód, «PiP»11.8-9 (1956), s. 424-436.

Niektóre zagadnienia problematyki rozwodowej na tle orzecznictwa i doktryny, «NP»12.6 (1956), s. 49-63.

\section{7}

Wtasność wód [Rozprawa doktorska], [w:] Zagadnienia cywilistyczne prawa wodnego, Warszawa 1957, s. 109-220.

- rec.: Witalis Ludwiczak, «PiP» 14.1 (1959), s. 152-156.

\section{8}

Glosa do orzeczenia $S N z 17$ X 1957 r. (3 CR 1172/57), «PiP» 13.12 (1958), s. 1084-1087.

\section{9}

Status prawny wód na tle prawa niektórych państw europejskich, «Gospodarka Wodna» 19.1 (1959), s. 7-13.

\section{0}

Prawo do wód $w$ przyszłej ustawie wodnej, «PiP»15.12 (1960), s. $973-984$.

\section{1}

Adekwatny czy konieczny zwiazek przyczynowy?, «Palestra» 5.6 i 7 (1961), s. 76-83; s. 13-36. 


\section{2}

Przyczynowość jako przestanka odpowiedzialności (zagadnienia wybrane), «NP»18.1 (1962), s. 27-46.

\section{7}

Zasady wspótżycia spotecznego $i$ spoteczno-gospodarcze przeznaczenie prawa a prawo wtasności, «NP» 23.6 (1967), s. 721-736.

\section{8}

Zarzut naduzycia prawa w sporze windykacyjnym, «NP» 24.1 (1968), s. 73-85.

\section{9}

Ochrona wtasności w polskim prawie cywilnym ('rei vindicatio' - 'actio negatoria') [Rozprawa habilitacyjna], Warszawa 1969, ss. 423, bibliogr.

- rec.: Jan Gwiazdomorski, «PiP» 25.3-4 (1970), s. 572-578.

- Andrzej Wiśniewski, «NP» 26.1 (1970), s. 102-103.

- Adam Szpunar, «NP» 26.3 (1970), s. 385-389.

- Andrzej Stelmachowski, «RPEiS» 33.1 (1971), s. 288-291.

Części składowe rzeczy, «NP» 25.1 (1969), s. 79-91.

W sprawie ogólnego obowiazku ochrony wtasności spotecznej na tle przepisu art. 127 \& 1 k.c., «NP» 25.2 (1969), s. 227-241.

Rec. monografii W. P. Szkriedow, Ekonomika i prawo (o principach issliedowanija proizwodstwiennych otnoszenii w swiazi s juridiczeskoj formoj ich wyrażenija), Moskwa 1967, «NP» 25.10 (1969), s. 1545-1551.

\section{1}

Glosa I do uchwaty Sadu Najwyższego - Izba Pracy i Ubezpieczeń Spotecznych z dnia 7 kwietnia 1970 r., III CZP $17 / 70$ [dot. odpowiedzialności zaktadu przemystowego za ujemne oddzialywanie na otoczenie], «OSPiKA » 15.9 (1971), poz. 169 c, s. 400-403.

\section{3}

Odszkodowanie za naruszenie posiadania, «NP» 29.1 (1973), s. 3-19. 
Glosa do uchwały składu Siedmiu Sędziów Sąu Najwyższego Izba Cywilna $z$ dnia 8 listopada 1971 r., III CZP 28/71 [dot. prawa wodnego; państwowej wtasności wody $i$ gruntów], «OSPiKA» 17.1 (1973), poz. 1c, s. 3-5.

\section{4}

L'adoption en droit de la République Populaire de Pologne, «Droit Polonais Contemporain» $1974 \mathrm{nr} 3$, s. 31-48.

Usynowlenije w zakonodatelstwie PNR, «Sowremiennoje Polskoje Prawo» 1974 nr 3, s. 31-48.

\section{6}

Glosa do wyroku Sądu Najwyższego - Izba Cywilna z dnia 18 czerwca 1975 r., II CP 238/75 [dot. wieczystego uzytkowania], «OSPiKA» 20.7-8 (1976), poz. 150 c, s. 346-350.

\section{7}

Odszkodowanie należne posiadaczowi za utracone pożytki z rzeczy, «NP» 33.4 (1977), s. 461-471.

W sprawie przyczynienia się poszkodowanego do powstania szkody (przyczynek do dyskusji nad treścia art. 362 k.c.), «NP» 33.6 (1977), s. 820-838.

Glosa do uchwaty składu 7 sędziów [SN] z 27 X 1975, III CZP 35/75 [dot. prawa pierwokupu], «NP» 32.1 (1977), s. 163-168.

\section{8}

Rzecz o stosunku prawnym prawa rzeczowego, «PiP» 33.5 (1978), s. $68-82$.

\section{1}

Les aspects civils des prestations de services fournies par les bureaux de voyages polonais aux touristes, «Journées de la Société de législation comparée» 1981, s. 219-229.

Die elterliche Sorge nach der Ehescheidung nach polnischem Recht, [w:] Deutsches Familienrechtsforum. Referate und Texte der Tagung vom 6. und 7. März 1981, Stuttgart 1981, s. 9-22. 
System prawa cywilnego. III. 1: Prawo zobowiazań - część ogólna, rozdz. III: Świadczenia, rozdz. IV: Naprawienie szkody, Wrocław-Warszawa 1981, s. 71-162; 163-308.

\section{2}

L'adoption en droit de la République Populaire de Pologne, «Studi Sassaresi» 7 (1979-1980) [wyd. 1982] s. 367-384.

\section{3}

La protection de l'enfant en droit polonais de la famille, [w:] La legislazione sui minori. Atti del Colloquio italo-polacco (Roma, 22-23 novembre 1979), Roma 1983, s. 1-22.

Stosunek art. 436 k.c. do art. 471 i 474 k.c., [w:] Studia z prawa cywilnego. Ksiega pamiatkowa dla uczczenia 50-lecia pracy naukowej prof. dr hab. Adama Szpunara, Łódź 1983, s. 125-134.

Warkałto Witold (1909-1983) [Wspomnienie pośmiertne] [oprac. wraz $z$ Wojciechem Markiem], «PiP» 38.12 (1983), s. 102-104.

\section{4}

Les biens de l'entreprise d'État dans la République Populaire de Pologne à la lumière des prescriptions sur la réforme économique, «Droit Polonais Contemporain» $1984 \mathrm{nr}$ 1-2, s. 23-33.

Les entreprises étrangères et avec participation étrangère en Pologne, «Droit Polonais Contemporain» 1984 nr 3-4, s. 5-24.

Gründung und Tätigkeit ausländischer Unternehmen und Unternehmen mit ausländischer Beteiligung in Polen, [w:] Rechtsfragen der deutsch-polnischen Wirtschaftsbeziehungen, Frankfurt am Main 1984, s. 33-48.

Family and Guardianship Law, [w:] General Principles of Law of the Polish People's Republic, Warszawa 1984, s. 209-230.

Zasada jedności wtasności państwowej a stosunek powiernictwa, «PiP» 39.10 (1984), s. 17-33.

\section{5}

Les éléments romanistes et les nouveaux éléments propres au droit socialiste dans l'institution de propriété par rapport au droit polonais contemporain, «Studia Iuridica» 12 (1985), s. 143-155. 
Ochrona dětí v polském rodinném právu. Rodiče a dětí v socialistickém právu rodinném, «Studia a Informace» 19 (1985).

Przedsiębiorstwa zagraniczne i z udziatem zagranicznym w Polsce, [w:] Rozprawy z prawa cywilnego. Ksiega pamiatkowa ku czci Witolda Czachórskiego, Warszawa 1985, s. 101-119.

\section{7}

Droit de la famille. Pologne, «Juris- Classeur Législation Comparée», 1987.

Succession. Pologne, «Juris- Classeur Législation Comparée», 1987.

Rec. monografii: Walerian Pańko, $O$ prawie wtasności i jego wspótczesnych funkcjach, Katowice 1984, «PiP» 42.10 (1987), s. $159-165$.

\section{8}

Sytuacja prawna mienia ogólnonarodowego, «PiP» 43.5 (1988), s. $14-25$.

Glosa do wyroku Sadu Najwyżzzego - Izba Cywilna i Administracyjna z dnia 19 marca 1987 r., III CRN 53/87 [dotyczaca oceny inwestycji budowlanych naruszających prawa osób trzecich], «OSPiKA» 32.7-8 (1988), poz. 173 c, s. 340-343.

\section{9}

Wandlungen der Eigentumsverhältnisse in der Volksrepublik Polen, «Recht in Ost und West» 1989 z. 3, s. 146-154.

Preobrażenija otnoszenij sobstwennosti w Polskoj Narodnoj Respublikie, «Sowremiennoje Polskoje Prawo» 1989 nr 1, s. 63-85.

1990

Wtasność Skarbu Państwa i państwowych osób prawnych $w$ świetle nowego art. 128 k.c., «PiP» 45.4 (1990), s. 30-39.

Przemiany stosunków wtasnościowych w Polskiej Rzeczypospolitej Ludowej, [w:] Prace cywilistyczne [Ksiega jubileuszowa ku czci prof. dr hab. Jana Winiarza], Warszawa 1990, s. 25-42. 
1991

The Legal Status of the Conceived Child, [w:] Medicine Ethics and Law, red. David J. Roy - Jean-Louis Baudovin - Marek Safjan Tomasz Dybowski, Montreal 1991, s. 293-308.

Les mutations des rapports de propriété en Pologne, «Droit Polonais Contemporain» 1990 [wyd. 1991] nr 1, s. 35-50.

Mienie komunalne, «Samorząd Terytorialny» 1.1-2 (1991), s. 5-15.

Komunalizacja przedsiębiorstw, «Samorząd Terytorialny» 1.5 (1991), s. 3-6.

Glosa do wyroku SN z dnia 28 listopada 1990 r. (III ARN 28/90), «Przegląd Sądowy» 1991 nr 3, s. 72-79.

1992

Mienie komunalne, [w:] Samorzad terytorialny i rozwój lokalny, Warszawa 1992, s. 239-257.

Prawo przed ekonomia [wywiad], «Życie Warszawy» 1992 nr 66.

1993

Centralny problem to ochrona praw człowieka [wywiad - dot. IX konferencji europejskich Sądów Konstytucyjnych], «Rzeczpospolita» $1993 \mathrm{nr} 107$.

Glosa II do uchwaty SN $z$ dnia 18 listopada 1992 r. (III CZP 133/32) [dot. zasiedzenia], «Przegląd Sądowy» 1993 nr 5, s. 114-117.

1995

Wykonywanie orzeczeń Trybunatu Konstytucyjnego o niezgodności ustaw z przepisami konstytucyjnymi, «Przegląd Sejmowy» 3.1 (1995), s. 21-34, Sum.

Witold Czachórski (1915-1995) [Wspomnienie pośmiertne], «PiP» 50.9 (1995), s. 87-89.

\section{6}

Wtasność w przepisach konstytucyjnych wedle stanu obowiazywania w 1996 roku, [w:] Konstytucja i gwarancje jej przestrzegania. Księga pamiatkowa ku czci Janiny Zakrzewskiej, Warszawa 1996, s. 301-327. 
Zasada sprawiedliwości spotecznej jako problem konstytucyjny w orzecznictwie polskiego Trybunatu Konstytucyjnego, [w:] Sadownictwo konstytucyjne, z. 1 [Materiaty konferencji polsko-litewskiej. Prace sędziów. Problematyka Trybunatu Konstytucyjnego w czasopiśmiennictwie. Stud. Mat. TK, II], Warszawa 1996, s. 73-89.

Rec. Jerzy Ignatowicz, Prawo rzeczowe, Warszawa 1995, «KPP» 5.3 (1996), s. 611-617.

1997

Nie ma wtasności absolutnej [wywiad], «Gazeta Prawna» 4.2 (1997), s. 30.

\section{8}

Mienie komunalne, [w:] Samorzad terytorialny. Zagadnienia prawne $i$ administracyjne, Warszaw 1998, s. 266-281.

Jerzy Ignatowicz (1914-1997) [Wspomnienie pośmiertne], «PiP» 53.5 (1998), s. 87-89.

\section{1}

Ochrona prawa wtasności na tle konstytucyjnej koncepcji źródet prawa $w$ orzecznictwie Trybunatu Konstytucyjnego, [w:] Trybunat Konstytucyjny. Ksiega XV-lecia, Warszawa 2001, s. 110-111. 